\title{
IDENTIFIKASI FAKTOR INTERNAL DAN FAKTOR EXTERNAL PENGEMBANGAN PARIWISATA PANTAI NATSEPA DENGAN PENDEKATAN COMMUNITY-BASED TOURISM
}

\author{
Yohana Aprilia de Lima \\ Sekolah Tinggi Pariwisata Ambarrukmo Yogyakarta \\ onadelima@gmail.com \\ Aditha Agung Prakoso \\ Sekolah Tinggi Pariwisata Ambarrukmo Yogyakarta \\ aaprakoso@gmail.com
}

\begin{abstract}
The purpose of this research is to identify the internal and external factor that obstruct or driven the development of Natsepa beach. This research used descriptive qualitative. The research was focused on identifying internal and external factors of development in Natsepa beach with Community-based tourism as an approach. The results of this study show that there are many physical and non-physical potential that can be developed into marine tourism the place itself is accessible and the government as the management already provide some facilities such as accommodation, etc. Indeed, the existing facilities need to be updated and improved. The potential need to be developed and managed properly, therefore proper planning and synergy among various parties is needed so each of activities can give a positive impact in economic and also environment to every parties.
\end{abstract}

Keywords: Natsepa beach; Potentia; Community-based tourism.

\begin{abstract}
Abstrak
Penelitian ini bertujuan untuk mengetahui faktor internal dan external yang menjadi penghambat dan pendorong dalam pengembangan pantai Natsepa. Penelitian ini menggunakan kualitatif deskriptif. Penelitian berfokus pada faktor internal dan external pengembangan pariwisata di Pantai Natsepa dengan pendekatan Community-based Tourism. Hasil penelitian ini adalah pantai Natsepa memiliki banyak potensi fisik maupun non-fisik yang dapat dikembangkan menjadi wisata bahari dan mudah untuk dijangkau serta tersedianya sarana akomodasi, fasilitas dll. Meskipun memang kondisi fasilitas yang ada perlu diperbaharui dan ditambahkan lagi. Potensi yang dimiliki oleh pantai Natsepa tentu saja perlu dikembangkan secara optimal maka dari itu sangat dibutuhkan perencanaan secara baik dan benar serta harus adanya sinergitas antara berbagai pihak agar setiap aktivitasnya dapat berjalan dengan lancar.
\end{abstract}

Kata Kunci: Pantai Natsepa; Potensi; Pariwisata Berbasis Masyarakat.

\section{A. PENDAHULUAN}

Pariwisata telah menjadi unsur penting dalam perkembangan perekonomian Indonesia. Pariwisata telah menjadi backbone perekonomian dan sektor strategis dalam perekonomian Indonesia. Tidak hanya berkontribusi terhadap pendapatan domestik bruto (PDB) ataupun devisa negara, tetapi pariwisata telah membuka lapangan kerja di masyarakat. Selain itu sektor pariwisata dikembangkan karena dianggap menjadi sumber industri andalan yang dapat memberikan lapangan pekerjaan, menguntungkan masyarakat, pemerintah, maupun pihak swasta, serta menggeser kegiatan-kegiatan industri manufaktur dan kegiatan ekonomi lainnya yang dapat mengeksploitasi sumber daya alam. Selain itu, kualitas 
merupakan hal penting dalam kegiatan pariwisata sebagai alat untuk menghadapi masa depan (Kiswantoro dan Damiasih, 2018). Maka dari itu, dalam pengembangan potensi pariwisata harus diimbangi sesuai dengan strategi pengembangan yang baik agar objek wisata tersebut dapat dimanfaatkan bagi peningkatan perekonomian masyarakat sekitar dan keberlanjutan dari objek tersebut. Penentuan strategi dalam Pengembangan pariwisata sangat dibutuhkan karena pariwisata merupakan industri yang dinamis, yang mana akan terus berkembang seiring dengan perkembangan zaman.

Setiap daerah di Indonesia mempunyai potensi wisata yang sangat beragam dengan keunikannya masing-masing. Seperti halnya di provinsi Maluku. Maluku memiliki banyak sumber daya serta potensi diantaranya sumber daya alam seperti hamparan pantai-pantai yang sangat indah dan alami, selain sumber daya alamnya yang terkenal. Maluku yang memiliki banyak potensi khususnya potensi alamnya yang terbilang masih alami dan belum terjamah oleh banyak orang menjadikan pantai tersebut selalu terjaga akan kebersihannya, selain itu atraksi-atraksi budaya yang menjadi ciri khas dari Maluku yaitu atraksi bambu gila yang sampai sekarang masih tetap terjaga kesakralannya. Menurut data dari Departemen Kebudayaan dan Pariwisata (2005) dalam Hiariey (2011), daerah Maluku merupakan kepulauan dengan luas wilayah $712.480 \mathrm{~km} 2$ terdiri dari sekitar 92,4\% lautan dan 7,6\% daratan dengan panjang garis pantai $11.000 \mathrm{Km}$. Selain itu, perairan Maluku dilalui oleh tiga Alur Laut Kepulauan Indonesia (ALKI) melewati pulau-pulau kecil yang tersebar hampir merata di seluruh wilayah Maluku.

Berdasarkan data di atas, dapat disimpulkan bahwa Maluku memiliki potensi wisata bahari yang tinggi mengingat luasnya wilayah lautan yang ada lebih luas dari wilayah daratan. Hal ini tentu saja membuat Maluku terkenal akan hamparan pantai yang indah serta memiliki potensi daya tarik wisata lainnya. Salah satu pantai yang terkenal di provinsi Maluku adalah pantai Natsepa.

Pantai Natsepa adalah salah satu daya Tarik wisata pantai yang sangat terkenal dan banyak dikunjungi oleh wisatawan. Pantai Natsepa itu sendiri memiliki potensi alam yang cukup banyak dan terbilang pantai yang banyak diminati oleh wisatawan nusantara atau mancanegara. Pantai Natsepa terletak di kawasan Negeri Suli kabupaten Maluku Tengah. Kawasan wisata ini merupakan salah satu kawasan wisata yang memiliki potensi diantaranya lokasi yang luas, keindahan laut dan pasir putih serta rujak khas Natsepa yang sudah terkenal kelezatannya. Di samping itu, pantai ini memiliki berbagai fasilitas maupun sarana dan prasarana yang menunjang sebagai kawasan wisata.

Pantai ini seharusnya dapat menjadi aset penting pariwisata yang ada di Kabupaten Maluku Tengah yang memberikan sumbangan Pendapatan Asli Daerah (PAD) yang tinggi dan menjadi sarana dalam memberdayakan masyarakat. Namun permasalahan yang terjadi adalah pengembangan pantai Natsepa sebagai obyek wisata tersebut belum optimal. Sarana prasarana yang ada masih belum lengkap serta kondisi pantai yang kurang terpelihara. Hal ini tentu saja dikuatkan melalui penelitian Handayawati et al (2010) tentang potensi wisata alam pantai-bahari, yang menjelaskan bahwa kebutuhan masyarakat terhadap wisata alam terutama di kawasan pesisir yang mengandalkan wisata bahari telah menjadikan pergeseran pola hidup masyarakat, meningkatnya taraf hidup masyarakat, serta kebutuhan akan sarana prasarana yang ada di lokasi wisata. Oleh karena itu, untuk mendukung daya jual objek wisata terhadap para wisatawan selain menampilkan keindahan alami objek wisata bahari, perlu dibuat rekayasa sarana dan prasarana yang sesuai dengan kebutuhan wisatawan. Maka dari itu dibutuhkan pengkajian ulang mengenai sarana dan prasarana yang ada di pantai Natsepa demi pengoptimalan pengembangan pantai Natsepa.

Selain itu ketersediaan atraksi wisata yang minim dan monoton di pantai Natsepa untuk para wisatawan juga menjadi masalah. Wisatawan yang berkunjung ke Pantai Natsepa hanya bisa menikmati keindahan pantainya tanpa ada kegiatan atraksi yang dapat dilakukan atau dinikmati oleh wisatawan demi perkembangan pariwisata di Maluku khususnya di pantai Natsepa. 
Dikeluarkannya UU Nomor 32 Tahun 2004 tentang Pemerintah Daerah dan UU Nomor 33 Tahun 2004 tentang Perimbangan Keuangan Pusat dan Daerah, memberi kesempatan yang besar bagi daerah untuk mengelola sumber daya alam yang dimiliki agar dapat memberikan hasil yang optimal. Akibatnya setiap pemerintah daerah berusaha semaksimal mungkin untuk meningkatkan perekonomian daerahnya. Potensi pariwisata yang tinggi di pantai Natsepa sudah seharusnya dapat dioptimalkan, bukan hanya dilihat sebagai potensi pendapatan daerah, namun sebagai salah satu upaya melestarikan kebudayaan daerah yang sudah mulai ditinggalkan. Selain itu hal lain yang tak kalah penting adalah keterlibatan masyarakat, banyak yang sering menyepelekan masyarakat dalam perencanaan pariwisata. Masyarakat memainkan peran yang besar sebagai pemilik dan pengelola suatu daya tarik wisata. Maka dari itu, masyarakat setempat perlu mengerti akan makna pariwisata supaya tidak menyimpang terhadap norma sosial, budaya, dan fisik daya tarik wisata tersebut. Untuk itu sangt perlu konsep pariwisata berbasis komunitas yang difungsikan sebagai konsep strategis dalam pengembangan pariwisata di dalam aspek kemasyarakatan, hal ini dapat berbentuk penekanan peran komunitas (masyarakat) lokal sebagai stakeholder penting atau utama dalam pengembangan pariwisata setempat. Hal ini tentu saja sejalan dengan pendapat Ardika (2005) dalam Purnamasari (2011), yang menjelaskan bahwa pengembangan pariwisata berbasis masyarakat menegaskan bahwa masyarakat bukan lagi menjadi obyek pembangunan akan tetapi sebagai penentu pembangunan itu sendiri.ardika 2005 dalam Purnamasari (2011). Pariwisata berbasis masyarakat merupakan aktivitas ekonomi penting yang jika dikembangkan dengan tepat dapat mengatasi sejumlah tantangan pembangunan termasuk pengurangan kemiskinan, pengembangan ekonomi lokal, perdamain, keselarasan masyarakat dan manajemen sumber daya alam dan lingkungan yang berkesinambungan (Damanik, et al, 2006) dalam (Purnamasari, 2011)).

Dari uraian tersebut, tujuan yang hendak dicapai adalah untuk mengetahui faktor internal dan external yang menjadi penghambat dan pendorong dalam pengembangan pantai Natsepa beserta rekomendasi strategi dengan pendekatan pariwisata berbasis masyarakat sebagai solusi dalam menghadapi hambatan yang ada. Oleh karena itu penulis mengangkat judul artikel ilmiah "Identifikasi Faktor Internal dan Faktor External Pengembangan Pariwisata Pantai Natsepa dengan pendekatan Community-Based Tourism".

Berdasarkan latar belakang diatas penulis dapat merumuskan permasalahan dalam penelitian ini yaitu, apa saja faktor pendukung dan penghambat pengembangan wisata di pantai Natsepa? serta bagaimana strategi pengembangan pantai Natsepa dengan konsep wisata berbasis masyarakat dalam mengatasi hambatan yang ada?

\section{B. METODE PENELITIAN}

Penelitian ini menggunakan pendekatan penelitian kualitatif. Teknik pengumpulan data dalam penelitian ini dilakukan melalui observasi, wawancara, dokumentasi dan kuesioner. Berdasarkan proses pelaksanaan pengumpulan data, penulis menggunakan participant observation, dimana penulis mengunjungi lokasi penelitian secara langsung dan terlibat dengan kegiatan atau aktivitas yang ada di lokasi penelitian yang merupakan sumber data dalam penelitian ini. Sedangkan berdasarkan segi instrumentasi, penelitian ini dilakukan melalui observasi terstruktur. Hal ini dikarenakan penulis telah merancang secara sistematis mengenai apa yang akan diamati, kapan, dan dimana tempatnya. Selain itu penulis juga mengumpulkan data melalui wawancara yang terstruktur, dimana penulis menggunakan pedoman wawancara yang telah disusun secara sistematis. Metode dokumentasi digunakan dalam penelitian ini sebagai pelengkap dari penggunaan metode observasi dan wawancara dimana pengumpulan data dilakukan dengan merekam jalannya proses observasi dan wawancara dalam bentuk tulisan, gambar dan rekaman suara. Penulis juga menggunakan kuesioner yang dibagikan kepada 
responden yang berisikan sejumlah pertanyaan tertulis untuk memperoleh informasi dari responden yang berkaitan dengan apa yang sedang diteliti.

\section{KAJIAN PUSTAKA}

Menurut UU nomor 10 tahun 2009 tentang kepariwisataan, daerah tujuan wisata adalah kawasan geografis yang spesifik berada dalam satu atau lebih wilayah administratif yang didalamnya terdapat kegiatan kepariwisataan dan dilengkapi dengan ketersediaan daya tarik wisata, fasilitas umum, fasilitas pariwisata, aksesibilitas, serta masyarakat yang saling terkait.

Cooper et al (1997) dalam Suwena (2010) mengemukakan bahwa terdapat 4 (empat) komponen yang harus dimiliki oleh sebuah destinasi wisata untuk pengembangan potensi kepariwistaan, yaitu:
a. Atraksi
b. Amenitas
c. Ancillary (Pelayanan Tambahan)

Nicole Hausler (2005) dalam International Tourism Forum mendefinisikan CBT sebagai bentuk pariwisata yang memberikan kesempatan kepada masyarakat lokal untuk mengontrol dan terlibat dalam manajemen dan pengembangan pariwisata. Menurut Hausler (2005) terdapat tiga unsur penting CBT yaitu keterlibatan masyarakat lokal dalam managemen dan pengembangan pariwisata, pemerataan akses ekonomi bagi seluruh lapisan masyarakat serta pemberdayaan politik (capacity building) masyarakat lokal yang bertujuan meletakkan masyarakat lokal sebagai pengambil keputusan. Anstrand (2006) mendefinisikan Community Based Tourism (CBT) sebagai pariwisata yang memperhitungkan dan menempatkan keberlanjutan lingkungan, sosial dan budaya, diatur dan dimiliki oleh masyarakat, untuk masyarakat.

Irawati \& Prakoso (2016), menguatkan definisi CBT yaitu berdasarkan prinsip keseimbangan dan keselarasan antara kepentingan berbagai stakeholders pembangunan pariwisata termasuk pemerintah, swasta dan masyarakat. Secara ideal prinsip pembangunan pariwisata " dari masyarakat, oleh masyarakat dan untuk masyarakat ". Dalam setiap tahapan pembangunan, yang dimulai dari perencanaan, pembangunan, pengelolaan dan pengembangan sampai dengan pemantauan (monitoring) dan evaluasi, masyarakat setempat harus dilibatkan secara aktif dan diberi kesempatan untuk berpartisipasi karena tujuan akhir adalah untuk meningkatkan kesejahteraan dan kualitas hidup masyarakat.

Prinsip dasar CBT menurut UNEP dan WTO (2005) dalam Suansri (2003) terbagi atas 10 prinsip dasar, yaitu:

1. Mengakui, mendukung dan mengembangkan kepemilikan masyarakat dalam industri pariwisata,

2. Mengikutsertakan anggota masyarakat dalam memulai setiap aspek,

3. Mengembangkan kebanggaan masyarakat

4. Mengembangkan kualitas hidup masyarakat.

5. Menjamin keberlanjutan lingkungan,

6. Mempertahankan keunikan karakter dan budaya di area lokal,

7. Membantu berkembangnya pembelajaran tentang pertukaran budaya pada masyarakat,

8. Menghargai perbedaan budaya dan martabat manusia,

9. Mendistribusikan keuntungan secara adil pada anggota masyarakat,

10. Berperan dalam menentukan persentase pendapatan (pendistribusian pendapatan) dalam proyek yang ada di masyarakat. 
Selain hal di atas, hal lain yang berkaitan dengan Community Based Tourism adalah kriteria ukuran kesuksesan Community Based Tourismyang didapat melalui penelitian evaluasi di beberapa negara di Asia (Rocharungsat,2008 dalam Prabawati, 2013):

1. Melibatkan Masyarakat Luas.

2. Manfaat dapat terdistribusikan secara merata pada semua masyarakat

3. Manajemen pariwisata yang baik

4. Kemitraan yang kuat baik ke dalam maupun ke luar

5. Keunikan atraksi

6. Konservasi lingkungan tidak terabaikan.

Berdasarkan berbagai pandangan ahli mengenai Community-Based Tourism pada kajian literatur, dapat disimpulkan bahwa, Pariwisata berbasis masyarakat (community-based tourism) di kembangakan berdasarkan prinsip keterlibatan masyarakat lokal dalam managemen dan pengembangan pariwisata, pemerataan akses ekonomi bagi seluruh lapisan masyarakat, keseimbangan dan keselarasan antara kepentingan stakeholders pembangunan pariwisata termasuk pemerintah, swasta, dan masyarakat, adanya prinsip pelestarian budaya dan keberlanjutan lingkungan. Prinsip-prinsip tersebut dapat dikategorikan dalam bidang sosial, ekonomi, budaya dan lingkungan, dengan penjabaran sebagai berikut:

Tabel 1 Prinsip-Prinsip Community-Based Tourism

\begin{tabular}{|c|c|c|c|}
\hline Sosial & Ekonomi & Budaya & Lingkungan \\
\hline 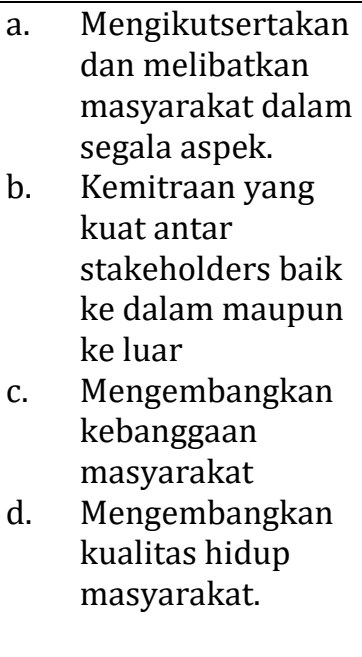 & $\begin{array}{l}\text { a. Manfaat dapat } \\
\text { terdistribusikan } \\
\text { secara merata dan } \\
\text { adil pada semua } \\
\text { masyarakat. } \\
\text { b. Mengakui, } \\
\text { mendukung dan } \\
\text { mengembangkan } \\
\text { kepemilikan } \\
\text { masyarakat dalam } \\
\text { industri } \\
\text { pariwisata. } \\
\text { c. Pemerataan akses } \\
\text { ekonomi bagi } \\
\text { seluruh lapisan } \\
\text { masyarakat. }\end{array}$ & $\begin{array}{l}\text { a. Adanya keunikan } \\
\text { atraksi } \\
\text { b. Mempertahankan } \\
\text { keunikan karakter } \\
\text { dan budaya di area } \\
\text { lokal } \\
\text { c. Membantu } \\
\text { berkembangnya } \\
\text { pembelajaran } \\
\text { tentang pertukaran } \\
\text { budaya pada } \\
\text { komunitas. } \\
\text { d. Menghargai } \\
\text { perbedaan budaya } \\
\text { dan martabat } \\
\text { manusia }\end{array}$ & $\begin{array}{l}\text { a.Menjamin } \\
\text { keberlanjutan } \\
\text { lingkungan. }\end{array}$ \\
\hline
\end{tabular}

\section{Hasil dan Analisis}

\section{Profil Pantai Natsepa}

Maluku merupakan provinsi kepulauan, dimana wilayah perairannya lebih luas dari wilayah daratannya. Dari hasil inventarisasi Dinas Kebudayaan dan Pariwisata Provinsi Maluku (2011) diketahui ada 302 potensi pariwisata terdiri dari potensi wisata sejarah $(20 \%)$, potensi wisata budaya $(15,2 \%)$, potensi wisata bahari $(36,6 \%)$ dan potensi wisata buatan $(1,8 \%)$. Berdasarkan data tersebut, dapat disimpulkan bahwa Maluku memiliki potensi wisata bahari sangat besar, mengingat wilayah perairan(lautan) lebih luas dari wilayah daratan. Hal ini tentu saja harus dimanfaatkan dengan baik. 
Pantai Natsepa merupakan salah satu dari sekian ribu pantai yang ada di provinsi Maluku dan merupakan kontributor terbesar untuk sektor pariwisata di Maluku, maka dari itu perencanaan dan pengembangan harus dilakukan dengan baik agar dapat memberikan manfaat yang besar bukan saja dalam pembangunan ekonomi tetapi juga pada aspek-aspek lain yang sangat fundamental bagi masyarakat di sekitar yakni rasa bangga akan tanah tumpah darah Maluku sehingga memupuk rasa persaudaraan yang sejati di antara setiap orang. Selain itu aspek keberlanjutan juga harus diperhatikan agar dapat terus bertahan dan dinikmati oleh generasi dimasa yang akan datang.

Potensi yang dimiliki Pantai Natsepa sangatlah beragam, mulai dari potensi non-fisik hingga potensi fisik. Potensi non-fisik yang dimiliki Pantai Natsepa yaitu memiliki nilai sejarah yang jelas, terdapat jajanan dan kuliner tradisional, terletak di desa yang masuk dalam kategori desa adat yang biasa di sebut Negeri karena memang dipimpin oleh raja dimana hal ini tentu saja dapat dijadikan sebagai potensi budaya karena memang sebuah Negeri adat sarat akan budaya. Selain itu terdapat tari-tarian tradisional seperti bambu gila, sau reka-reka, dll. Sedangkan potensi fisiknya terdiri dari letaknya yang strategis karena tidak jauh dari pusat ibu kota provinsi Maluku, Pantai dengan pasir putih halus dengan ombak yang cenderung tenang, pemandangan yang disuguhkan masih alami dan indah serta pemandangan alam bawah dan atas laut yang indah.

Pantai Natsepa dikelola langsung oleh Pemerintah yaitu Dinas Pariwisata, Pemuda dan Olahraga Kabupaten Maluku Tengah. Di Pantai Natsepa masih belum ada organisasi khusus sejenis POKDARWIS atau Kelompok Sadar Wisata guna membantu pengelolaan dan promosi Pantai Natsepa. Kualitas sumber daya manusia yang ada juga masuk dalam kategori rata-rata, namun sebagian sudah mulai berdaya dan mulai membuka usaha di Pantai Natsepa. Sumber pendanaan pengembangan dan pengelolaan kegiatan wisata di Pantai Natsepa secara menyeluruh adalah dari APBN dan APBD melalui dana alokasi khusus atau DAK sehingga segala sesuatu mengenai perencanaan, perbaikan, pengelolaan dan pengembangan segala sesuatu harus berdasarkan prosedur serta peraturan perundang-undangan yang berlaku dan menunggu persetujuan dari pihak yang terkait.

Salah satu kawasan wisata di Maluku yang memiliki potensi dan sering dikunjungi oleh para wisatawan adalah Pantai Natsepa. Pantai Natsepa merupakan salah satu kawasan wisata yang memiliki potensi diantaranya lokasi yang luas, keindahan laut dan pasir putih serta rujak khas Natsepa yang sudah terkenal kelezatannya. Pantai Natsepa adalah salah satu Objek Wisata Alam yang berlokasi di Negeri Suli , Kecamatan Salahutu, Kabupaten Maluku Tenggah dan secara geografis terletak antara $3^{\circ}, 15^{\circ}-3^{\circ}, 40^{\circ}$ lintang selatan dan $126^{\circ}, 30^{\circ}-127^{\circ}$ Bujur Timur, sedangkan secara administratif terletak di sebelah utara dengan gunung Salahutu, sebelah selatan dengan teluk Baguala, sebelah timur dengan Negeri Tulehu dan Negeri Tial, sebelah barat dengan Negeri Passo. Jarak yang harus ditempuh untuk mencapai Pantai Natsepa adalah yakni $\pm 15 \mathrm{Km}$ dari pusat kota Ambon dan $\pm 23 \mathrm{Km}$ dari Bandara Internasional Pattimura. Pantai Natsepa sangat mudah untuk diakses, hal ini dikarenakan letak pantai ini yang sangat strategis dan mudah dijangkau.

Fasilitas-fasilitas yang ada di Pantai Natsepa yaitu penginapan, hotel, tempat parkir, warung makan, gazebo atau tempat duduk, tempat parkir, tempat sampah, kamar mandi, toilet dan toko suvenir. Fasilitas tersebut di dapat dikatakan masih belum lengkap dan memadai. Selain itu di Natsepa juga terdapat wahana air seperti banana boat, donut, dan penyewaan perahu tradisional. Pantai Natsepa dikelola langsung oleh Pemerintah yaitu Dinas Pariwisata, Pemuda dan Olahraga Kabupaten Maluku Tengah, sehingga sumber pendanaan semua pengembangan dan pengelolaan kegiatan wisata di Pantai Natsepa adalah berasal dari pemerintah. Selain itu Pantai Natsepa juga sudah mempunyai ijin atau regulasi yang jelas terkait dengan pengadaan kegiatan wisata di Negeri Suli.

Kualitas sumber daya manusia yang ada juga masuk dalam kategori rata-rata, namun sebagian sudah mulai berdaya dan mulai membuka usaha di Pantai Natsepa meskipun kualitas produk dan layanan

54 | Barista: Jurnal Kajian Bahasa dan Pariwisata, Volume 6 Nomor 2, 2019: 49-65 
yang disediakan masih dibawah rata-rata. Masyarakat sekitar memanfaatkan Kawasan wisata ini dengan berbagai bentuk kegiatan usaha. Sebagian besar menjadikan kegiatan usaha di Kawasan ini sebagai mata pencaharian utama. Berdasarkan hasil observasi yang dilakukan, berbagai kegiatan usaha di pantai Natsepa yaitu: usaha rumah makan, jajanan makanan dan minuman serta usaha penjualan rujak yang merupakan jenis usaha terbanyak dikembangkan oleh masyarakat dan merupakan pendukung wisata kuliner yang kebanyakan dilakukan oleh kelompok perempuan. Rujak merupakan kuliner unggulan di pantai Natsepa. Banyak wisatawan yang berkunjung ke pantai Natsepa untuk menikmati kuliner ini sambal menikmati keindahan pantai. Hal inilah yang membuat pantai ini selalu ramai dikunjungi oleh wisatawan. Selain rujak, masyarakat juga mengembangkan usaha es kelapa muda yang merupakan kuliner wajib di setiap objek wisata pantai. Di pantai Natsepa, masyarakat juga menyediakan jasa sewa perahu untuk berkeliling menikmati keindahan bawah laut di pantai Natsepa. Berkeliling menggunakan perahu merupakan salah satu daya Tarik wisata bahari di pantai Natsepa. Kegiatan usaha penyewaan pelampung, bantal renang, banana boat juga telah menjadi kegiatan yang mendukung wisata bahari di pantai Natsepa. Hubungan antar sumber daya manusia di pantai Natsepa juga dalam keadaan yang baik dan sampai saat ini masih belum ada pesaing sejenis Pantai Natsepa di Negeri Suli. Berdasarkan hal tersebut, dapat disimpulkan bahwa pemberdayaan dan partisipasi masyarakat di pantai Natsepa sudah sangat baik dan harus terus ditingkatkan. Selain turut melakukan kegiatan usaha, masyarakat juga turut berperan penjual tiket masuk dan sebagai tukang parkir.

Pelayanan yang diberikan di Pantai Nastepa sangat baik, karena memang staf dan masyarakat di sana sangat ramah sehingga banyak wisatawan yang merasa puas dan nyaman. Selain itu hal ini didukung dengan karakteristik pantai Natsepa yang mempunyai ombak yang cenderung tenang karena memang terletak di dalam teluk sehingga pantai ini sangat aman untuk berenang, snorkeling, dll. Masyarakat sekitar beserta pihak pengelola juga menjalin kerja sama yang sangat baik dalam hal menjaga keamanan lingkungan di Pantai Natsepa jadi tingkat kejahatan di Pantai Natsepa bisa dikatakan sangat minim.

Pantai Natsepa terletak di desa Suli yang merupakan kawasan pesisir yang berada di pulau Ambon. Pulau Ambon secara tektonik masuk dalam kategori rawan gempa. Tatanan tektonik menunjukkan bahwa pulau Ambon dan pulau Seram dijepit oleh 2 sumber gempa utama. Melihat fakta bahwa pulau Ambon merupakan pulau yang rawan gempa bumi maka dari itu perlu adanya upaya mitigasi dan adaptasi mengenai gempa bumi dan tsunami baik untuk wisatawan, pengelola serta masyarakat sekitar mengingat gempa bumi dapat terjadi kapan saja.

Pantai Natsepa juga memiliki sejarahnya tersendiri, dahulu kala kapitan-kapitan di Hulimual dan Suli sedang mempersiapkan diri untuk berperang dengan kapitan Sahulau, kapitan Hulimual dan Kapitan Suli berkumpul di pantai Suli. Pantai tersebut belum ada nama sehingga kapitan-kapitan tersebut menamakannya Natarepa. Kata Natarepa di ambil dari bahasa tanah Negeri Suli, Natarepa yang artinya tempat persinggahan para Gusepa. Gusepa merupakan Kapal-kapal Kapitan yang terbuat dari Gaba-gaba (pelepah dahan sagu). Kata Natsepa merupakan serapan dari bahasa tanah Negeri Suli yaitu Natarepa yang artinya tempat persinggahan kapal-kapal kapitan. Jadi Natsepa adalah tempat persinggahan kapalkapal kapitan Hulimual dan Kapitan Suli. Hal ini menunjukkan bahwa pantai Natsepa memiliki nilai historisnya tersendiri yang mana tentu saja harus terus dilestarikan agar tidak punah.

Pemerintah sering melakukan promosi melalui festival, event serta melalui website dan sosial media sehingga dapat memperkenalkan Pantai Natsepa bukan hanya untuk wisatawan lokal tapi juga wisatawan nusantara dan mancanegara. Selain itu masyarakat dan wisatawan juga turut berperan dalam kegiatan promosi melalui word of mouth atau dari mulut ke mulut. Meskipun promosi yang dilakukan sudah secara digital, namun pemanfaatan dan penggunaan teknologi di pantai Natsepa masih sangat minim. 
Kondisi kebersihan lingkungan di pantai Natsepa juga harus mendapat perhatian khusus. Hal ini dikarenakan banyak sampah yang berserakan di dalam Kawasan pantai ini. Salah satu penyebab berseraknya sampah di pantai ini adalah kurangnya tempat sampah dan kurangnya perhatian dari pihak pengelola, masyarakat dan pelaku usaha yang terlibat. Sering kali sampah yang telah penuh di tempat sampah dibiarkan dan ditumpuk dalam waktu yang lama, sehingga terkadang sampah tersebut menjadi berserakan karena pengaruh angin dan wisatawan yang bingung harus membuang sampah kemana dikarenakan tempat sampah yang ada sudah penuh. Permasalahan tentang sampah merupakan hal yang serius, pihak pengelola perlu bekerja sama dengan masyarakat dan pihak swasta yang terlibat untuk mengembangkan strategi untuk mengatasi permasalahan sampah di pantai Natsepa.

\section{Isu Strategis}

Berikut ini merupakan berbagai isu-isu strategis terkait dengan pengembangan pantai Natsepa yang muncul dan perlu ditindaklanjuti.

a. Perlunya pengemasan kembali sumber daya alam dan budaya serta nilai-nilai sejarah yang ada di pantai Natsepa.

Beberapa sumber daya alam dan budaya yang ada di pantai Natsepa masih perlu dikemas, diolah dan pasarkan dengan baik dan cermat. Hal tersebut untuk memperkuat image pantai Natsepa sebagai objek wisata yang merupakan pioneer wisata di Maluku dengan keunikan dibandingkan destinasi lainnya di wilayah Maluku. Selain potensi alam, terdapat juga potensi budaya yang sangat besar. Pantai Natsepa yang terletak di desa Suli yang merupakan salah satu desa adat di provinsi Maluku menyimpan beragam tradisi dan warisan budaya seperti tari-tarian tradisional misalnya bambu gila dan sau reka-reka. Selain itu aktivitas sehari-hari dan mata pencaharian masyarakat di desa Suli yang mayoritasnya sebagai nelayan juga dapat dijadikan daya Tarik dimana wisatawan dapat melihat secara langsung kehidupan masyarakat Suli. Pantai Natsepa juga terkenal dengan jajanan khas yaitu rujak Natsepa dan jajanan tradisional lainnya serta didukung dengan sumber daya alam yang sangat menarik yaitu keindahan pantai dan bawah lautnya. Hal ini tentu saja merupakan potensi yang sangat menarik dan dapat dikemas menjadi suatu festival yang beragam dan dapat dilaksanakan dapat waktu yang berbeda agar adanya diversifikasi dan dapat menarik wisatawan untuk datang.

\section{b. Penataan sarana prasarana yang masih berantakan.}

Tata letak dan kelola fasilitas yang ada di Pantai Natsepa juga perlu di tata kembali karena kondisinya yang sangat tidak beraturan dan membuat pantai Natsepa terkesan kumuh dan berantakan.

c. Peran serta masyarakat lokal dalam pengelolaan objek dan atau kawasan wisata sudah sangat baik dan harus terus ditingkatkan.

Masyarakat merupakan salah satu aspek penting yang perlu diperhatikan dalam suatu kegiatan wisata mengingat masyarakatlah yang paling mengerti kondisi yang ada di suatu objek wisata dan masyarakat juga yang akan merasakan dampak yang ditimbulkan dari setiap pembangunan yang ada di objek wisata tersebut karena mereka tinggal dan hidup di lingkungan tersebut. Maka dari itu konsep pengembangan wisata berbasis masyarakat harusnya menjadi acuan pengembangan suatu objek wisata. Tingkat pemberdayaan dan partisipasi masyarakat di Pantai Natsepa sudah sangat baik. Banyak masyarakat yang sudah mau terlibat baik secara langsung maupun tidak langsung. Secara langsung, 
masyarakat banyak yang ikut berjualan aneka jajanan seperti rujak, pisang goreng, dll. Selian itu banyak masyarakat yang menyediakan layanan persewaan bantal berenang, perahu, banana boat, tikar, menjadi tukang parkir.

d. Kondisi dan situasi yang Bersih, Nyaman, Aman serta Indah harus selalu dikondisikan, dengan melibatkan masyarakat serta kelompok sadar wisata sebagai ujung tombak wisata setempat.

Hal penting lainnya yang perlu diperhatikan adalah kebersihan lingkungan baik di dalam Kawasan wisata maupun lingkungan sekitarnya. Lingkungan di dalam dan sekitar suatu objek wisata harus terjaga agar selalu bersih dan bebas dari sampah karena jika dipenuhi dengan sampah akan berdampak pada kenyamanan wisatawan. Wisatawan akan terganggu ketika mengunjungi suatu objek wisata dan ternyata dipenuhi dengan sampah karena akan mengurangi keindahan alam yang ada dan mengganggu penciuman.
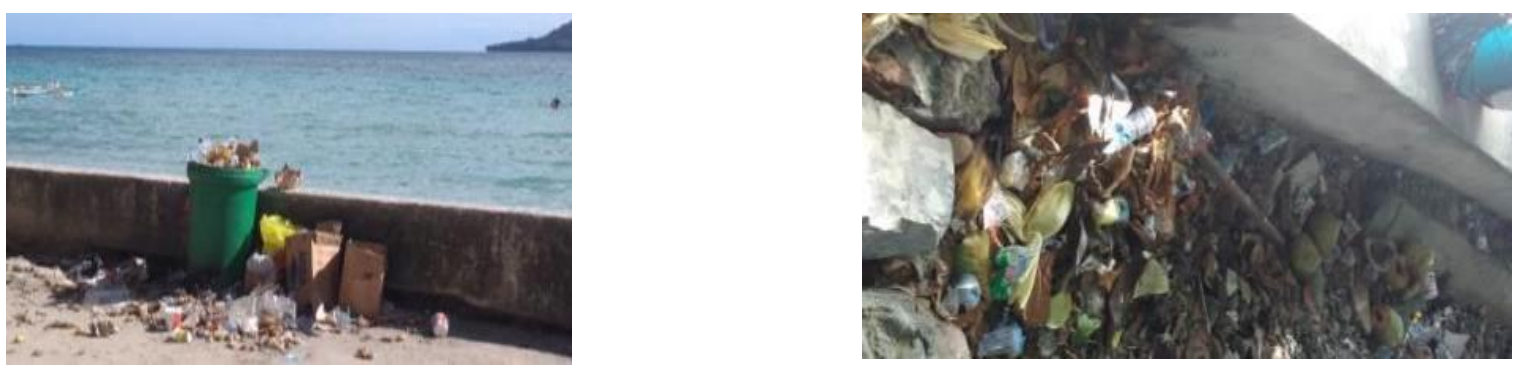

Kondisi kebersihan lingkungan di Pantai Natsepa masuk dalam kategori buruk karena banyak sampah yang berserakan. Hal ini tentu saja harus mendapat perhatian yang serius dari pihak pengelola dan masyarakat, wisatawan juga harus turut bekerja sama untuk menjaga kebersihan lingkungan. Apalagi kegiatan wisata di Pantai Natsepa didominasi oleh wisata bahari maka dari itu sangat penting untuk menjaga kebersihan agar baik di pantai maupun bawah lautnya tidak tercemar dengan sampah. Selain itu, keamanan pada suatu objek wisata merupakan hal yang penting dalam industri pariwisata dan dapat menjadi nilai tambah dan peluang untuk dikunjungi wisatawan. Keamanan memiliki dampak yang cukup besar terhadap keberlangsungan aktivitas perjalanan dan pariwisata. Keadaan dan kondisi lingkungan baik di dalam dan di luar Kawasan pantai Natsepa sekitarnya dapat dikatakan aman, karena memang minim tindakan kejahatan dan tidak ada premanisme. Sikap pengelola dan masyarakat setempat juga tidak terindikasi mengganggu wisatawan yang datang di Pantai Natsepa. Selain itu ombak di Pantai Natsepa juga cenderung kecil karena memang letaknya di dalam Teluk sehingga aman untuk berenang dan juga sudah dilengkapi dengan pemecah ombak. Meskipun sekarang ini memang situasi di Pantai Natsepa dalam keadaan aman dan baik-baik saja namun tetap saja perlu adanya standar keamanan dan keselamatan yang jelas dan harus implementasikan dan terus diperiksa pelaksanaannya sebagai tindakan preventif untuk mencegah hal-hal yang tidak diinginkan.

\section{Analisis Komponen Pariwisata}

a. Atraksi

1) Something To See

a) Pemandangan alam 
Pantai Natsepa memiliki panorama yang sangat indah berupa hamparan pasir putih yang bersih, lautan yang jernih yang dipenuhi dengan beraneka ragam biota laut dan juga terumbu karang.

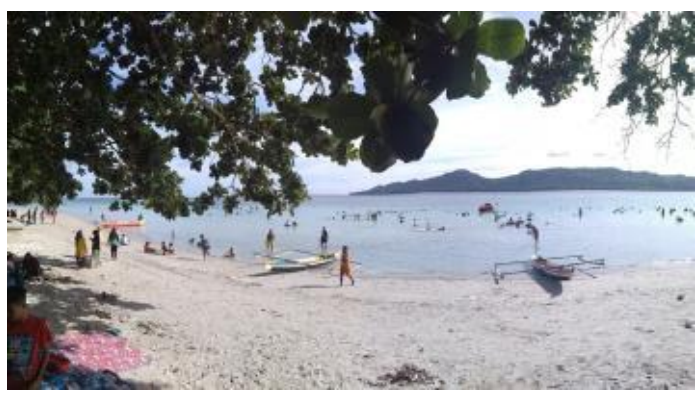

b) Olahraga, wahana air dan kegiatan rekreasi.

Pantai Natsepa juga nemawarkan berbagai aktivitas yang bisa dinikmati selain pemandangan alamnya, dimana wisatawan yang datang bisa melihat aktivitas dari wisatwan lainnya yang sedang melakukan olahraga pantai seperti bermain bola volley dan bola kaki, wahana air seperti banana boat ataupun bersantai sambal melihat kegiatan rekreasi seperti naik perahu dan outbond.
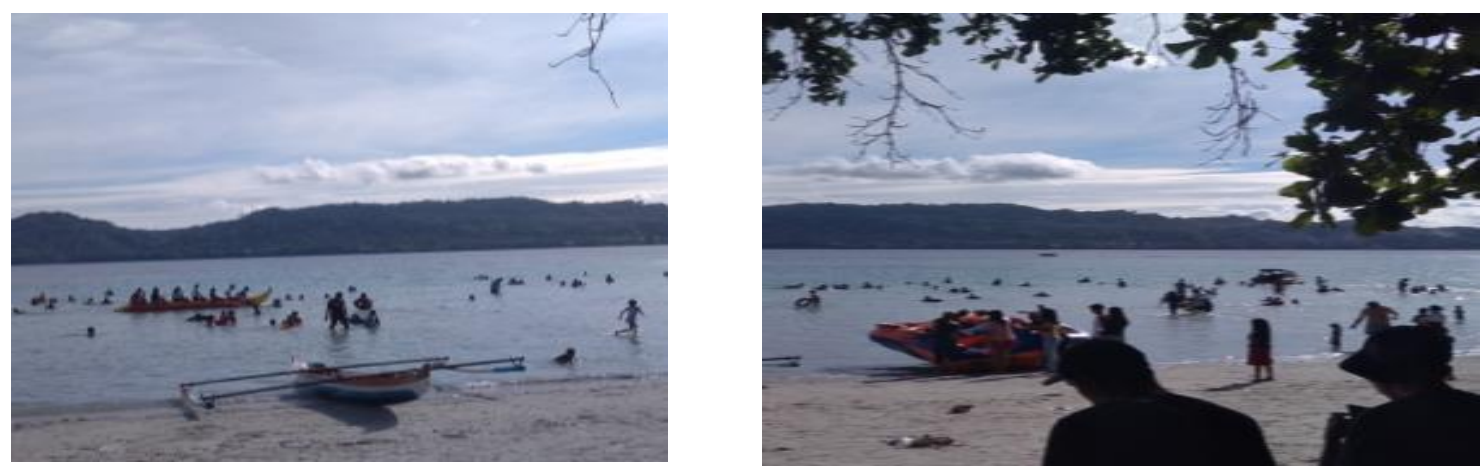

2) Something To Do
a) Berenang
b) Snorkeling
c) Olahraga Pantai (Volly, bola kaki)
d) Wisata Kuliner
e) Wahana Air (Banana Boat/ Donut Boat)
f) Rekreasi (Outbond, naik perahu, bersantai)

\section{3) Something To Buy}

\section{a) Makanan Dan Minuman}

Saat sedang berada di dalam Kawasan pantai Natsepa, wisatawan dapat membeli beragam makanan yang telah tersedia. Makanan yang dijual di pantai Natsepa kebanyakan didominasi oleh makanan dan jajanan tradisional seperti rujak Natsepa yang sudah

58 | Barista: Jurnal Kajian Bahasa dan Pariwisata, Volume 6 Nomor 2, 2019:49-65 
melegenda, sagu gula, sukun goreng, ubi goreng seerta jajanan khas daerah pantai lainnya seperti es kelepa, bakso, dll.

b) Cinderamata/Souvenir

Di pantai Natsepa juga menyediakan cinderamata atau souvenir khas Maluku yang dapat dibeli oleh wisatawan untuk dijadikan sebagai oleh-oleh maupun dijadikans sebagai kenang-kenangan. Namun souvenir yang tersedia belum emnunjukan kekhasan dari pantai Natsepa ini tersendiri ataupun Negeri Suli yang merupakan lokasi pantai ini.

c) Jasa penyewaan

Di pantai Natsepa tersedia tempat penyewaan perahu tradisional milik masyarakat sekitar untuk berkeliling menikmati pemandangan pantai dan laut. Selain itu terdapat juga penyewaan bantal berenang, tikar, wahana air seperti Banana Boat, dlll.

b) Amenitas

Amenitas mempunyai peran yang sangat besar bagi wisatawan yang akan mengunjungi suatu destinasi. Fasilitas-fasilitas yang ada di Pantai Natsepa yaitu penginapan, hotel, tempat parkir, warung makan dan kios, gazebo atau tempat duduk, tempat parkir, tempat sampah, kamar mandi, toilet dan toko suvenir. Selain itu di Natsepa juga terdapat wahana air seperti banana boat, donut, dan perahu.

Ketersediaan fasilitas di pantai Natsepa memang mampu mendukung kegiatan dan kebutuhan dasar wisatawan, namun fasilitas tersebut masih belum sepenuhnya lengkap, memadai dan bahkan ada yang tidak layak untuk digunakan sebagai fasilitas. Melihat kondisi fasilitas yang ada di Pantai Natsepa yang cukup memprihatinkan padahal pantainya memiliki daya tarik yang luar biasa menarik, maka dari itu pihak pengelola perlu menambahkan dan memperbaharui kembali fasilitas yang ada. Tata letak dan kelola fasilitas yang ada di Pantai Natsepa juga perlu di tata kembali karena kondisinya yang sangat tidak beraturan dan membuat pantai Natsepa terkesan kumuh dan berantakan.
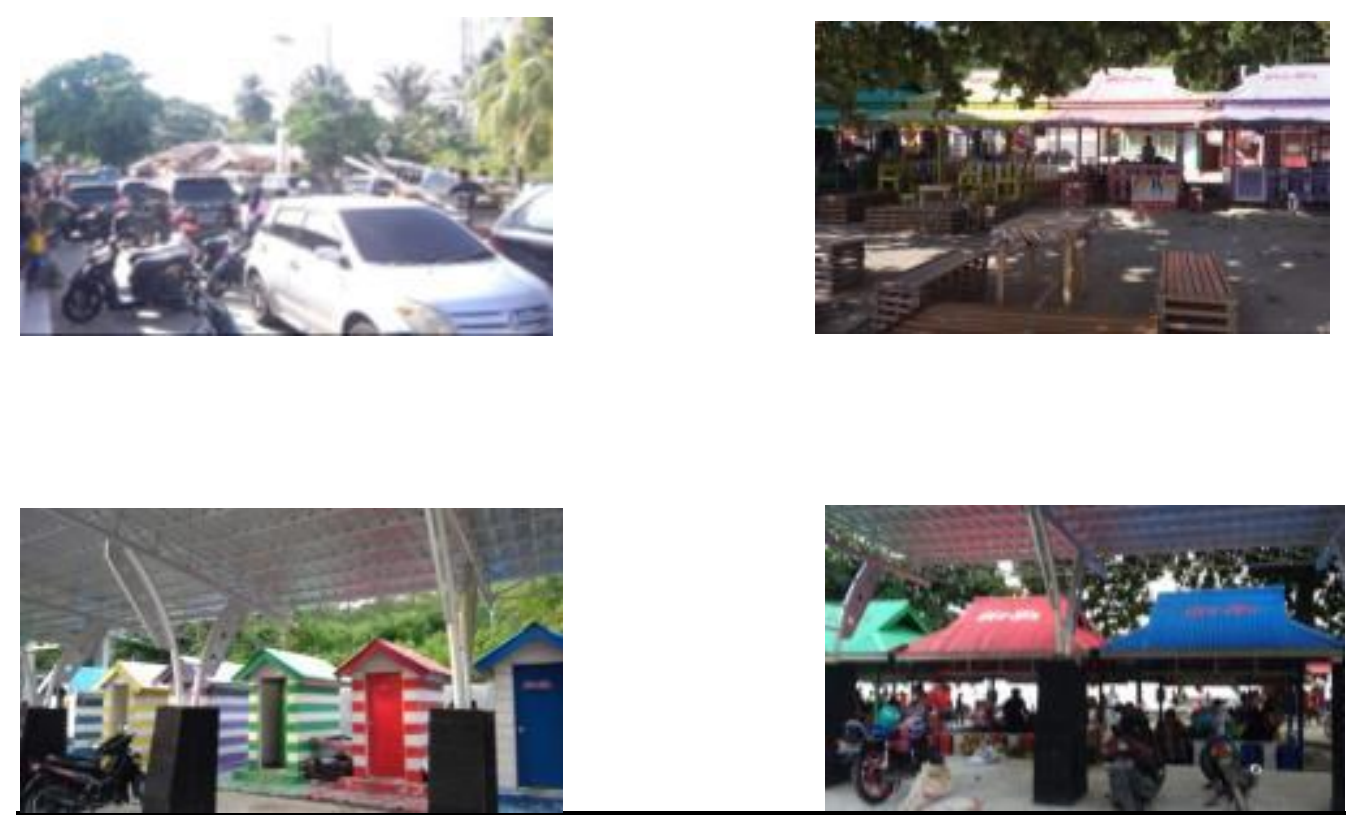

Barista: Jurnal Kajian Bahasa dan Pariwisata, Volume 6 Nomor 2, 2019: 49-65 


\section{c) Aksesibilitas}

Pantai Natsepa terletak di tempat yang sangat strategis dimana dapat ditempuh 15 menit dari ibu kota provinsi Maluku dan 30 menit dari Bandara Internasional Pattimura. Hal inilah yang membuat akses menuju Pantai Natsepa menjadi sangat mudah. Ada beberapa alternatif transportasi yang bisa digunakan untuk mencapai lokasi ini. Dari pusat kota, dengan menggunakan angkot (Rp. 5.000/orang). Angkot mulai beroperasi pada pukul 05.30 - 21.00 WIT. Ada juga alternatif lain, yakni menggunakan mobil carteran maupun taxi dengan kisaran harga di atas Rp. 100.000 .

\section{Analisis penerapan CBT di Pantai Natsepa}

Berdasarkan hasil wawancara, observasi, dan dokumentasi, penerapan CBT sudah cukup terimplementasi dengan baik sesuai dengan prinsip-prinsip CBT yang didapatkan melalui pengkajian beberapa pendapat ahli. Berdasarkan berbagai pandangan ahli mengenai community-based tourism pada kajian literatur, dapat disimpulkan bahwa, Pariwisata berbasis masyarakat (community-based tourism) di kembangakan berdasarkan prinsip keterlibatan masyarakat lokal dalam managemen dan pengembangan pariwisata, pemerataan akses ekonomi bagi seluruh lapisan masyarakat, keseimbangan dan keselarasan antara kepentingan stakeholders pembangunan pariwisata termasuk pemerintah, swasta, dan masyarakat, adanya prinsip pelestarian budaya dan keberlanjutan lingkungan.

Masyarakat merupakan salah satu aspek penting yang perlu diperhatikan dalam suatu kegiatan wisata mengingat masyarakatlah yang paling mengerti kondisi yang ada di suatu objek wisata dan masyarakat juga yang akan merasakan dampak yang ditimbulkan dari setiap pembangunan yang ada di objek wisata tersebut karena mereka tinggal dan hidup di lingkungan tersebut. Maka dari itu konsep pengembangan wisata berbasis masyarakat harusnya menjadi acuan pengembangan suatu objek wisata.

Tingkat pemberdayaan dan partisipasi masyarakat di Pantai Natsepa sudah sangat baik. Banyak masyarakat yang sudah mau terlibat baik secara langsung maupun tidak langsung. Secara langsung, masyarakat banyak yang ikut berjualan aneka jajanan seperti rujak, pisang goreng, dll. Selian itu banyak masyarakat yang menyediakan layanan persewaan bantal berenang, perahu, banana boat, tikar, menjadi tukang parkir.

Berdasarkan penerapan konsep CBT dari sisi ekonomi, pada dasarnya pengelola pantai Natsepa adalah pemerintah. Meskipun demikian, pemerintah mengakui, mendukung dan mengembangkan kepemilikan masyarakat di Pantai Natsepa, dimana masyarakat lokal diberikan kesempatan untuk mengembangkan usaha-usaha yang diminati dan sesuai dengan kebutuhan wisatawan tetapi tetap dalam pengawasan pemerintah. Pendapatan yang diperoleh dari hasil usaha tersebut tidak diserahkan ke pemerintah, pemerintah hanya mengambil keuntungan dari biaya karcis masuk dan penyewaan penginapan. Pemerintah benar-benar menyediakan wadah dan memberikan kesempatan bagi masyarakat sekitar untuk mengembangkan usahanya masing-masing. Jadi dapat disimpulkan bahwa manfaat dapat terdistribusikan secara merata dan adil pada semua masyarakat serta adanya pembagian peran yang adil antara masyarakat, pemerintah dan stakeholders. Selain itu partisipasi ekonomi masyarakat juga dapat dikatakan cukup baik meskipun dengan skill yang terbatas, dimana masyarakat sudah mampu memanfaatkan peluang kerja dan peluang usaha dari adanya kegiatan wisata di pantai Natsepa menjadi pekerjaan dan usaha produktif. Penerapan prinsip CBT dalam pengembangan pariwisata dari segi ekonomi di pantai Natsepa sudah terimplementasi dengan baik, hal ini dikarenakan sudah adanya partisipasi aktif dari masyarakat, manfaat dapat terdistribusika secara merata pada semua masyarakat serta adanya pengakuan dan dukungan pengembangan usaha penunjang kegiatan wisata di Pantai Natsepa. Hal ini dikarenakan sudah mulai munculnya kesadaran dari masyarakat untuk turut serta 
berpartisipasi serta masyarakat juga cukup cerdas dalam melihat kesempatan dan peluang usaha yang ada meskipun dengan skill yang terbatas.

Dilihat dari perspektif budaya, keunikan atraksi di pantai Natsepa masih belum ditonjolkan, padahal banyak potensi-potensi yang bisa dikembangkan menjadi atraksi yang menarik dan unik. Pantai Natsepa terletak di salah satu Negeri (sebutan untuk desa adat di Maluku) yang mempunyai banyak potensi budaya, namun daya tarik dan atraksi wisata yang ada di pantai Natsep belum sepenuhnya mengangkat ataupun mengandung karakter dan budaya lokal yang ada. Sehingga menghambat proses perkembangan pembelajaran tentang pertukaran budaya antar wisatawan dengan masyarakat lokal maupun sebaliknya. Hal ini dapat terjadi dikarenakan kualitas dan skill dari sumber daya manusia yang masih sangat terbatas sehingga belum mampu memanfaatkan potensi-potensi budaya setempat.

Sedangkan, penerapan prinsip CBT yang berkaitan dengan lingkungan di pantai Natsepa masih kurang baik, kesadaran akan pentingnya prinsip keberlanjutan lingkungan di pantai Natsepa masih minim. Banyak sampah yang berserakan, jika dibiarkan terus menerus maka lingkungan yang ada bisa tercemar dan akhirnya aktivitas wisata akan terganggu serta akan timbul ketidaknyamanan yang mana hal ini tentu saja merupakan ancaman. Menanggapi hal tersebut, tentu saja bukan hanya tugas pemerintah sebagai pengelola, namun dibutuhkan kerjasama yang baik antara masyarakat, stakeholders serta wisatawan agar dapat terciptanya lingkungan yang bersih. Sampah merupakan permasalahan yang cukup serius di setiap tempat wisata, permasalahan mengenai sampah di pantai Natsepa disebabkan oleh ketidaksadaran wisatawan serta masyarakat tentang dampak negatif dari sampah yang bias mengancam keberlangusngan kegiatan wisata di pantai Natsepa. Selain itu pihak pemerintah sebagai pengelola juga masih belum tegas dalam menanggapi permasalahan sampah ini, diperlukan pengkajian pengelolaan sampah yang baik dan benar agar nantinya masalah sampah di pantai Natsepa dapat teratasi.

Berdasarkan hasil analis diatas, berikut ini factor internal dan external yang muncul:

a. Faktor Pendukung

1) Faktor Internal

a) Tingkat partisipasi dan keterlibatan masyarakat yang cukup tinggi.

b) Memiliki banyak potensi yang bisa dikembangkan

2) Faktor External

a) Banyak dikunjungi oleh wisatawan

b. Faktor Penghambat

1) Faktor Internal

a) Keterbatasan SDM

b) Skill SDM yang ada masih dibawah rata-rata

c) SDM yang ada terbilang cukup atau rata-rata

d) Prosedur pengelolaan sampah dari pihak pengelola yang masih belum jelas dan tegas

e) Keunikan karakter dan budaya lokal masih belum dimanfaatkan dengan baik.

2) Faktor External

a) Tingkat kesadaran masyarakat dan wisatwan akan pentingnya mempuang smapah pada tempatnya masih minim.

b) Rawan bencana alam

Faktor pendukung dan penghambat pada suatu tempat wisata harus dikaji dengan benar agar nantinya dapat dibuat solusi yang tepat untuk menangani masalah-masalah yang dapat menghambat kegiatan wisata di suatu tempat. Maka dari itu diperlukan strategi untuk 
menanggulangi hal tersebut untuk pengembangan Pantai Natsepa agar lebih maju dan berdaya saing.

1. Diversifikasi daya tarik wisata dengan memanfaatkan karakter dan budaya lokal.

Hal ini dapat diwujudkan misalnya dengan membuat festival budaya dan pagelaran seni mengingat selain potensi alam, terdapat juga potensi budaya yang sangat besar. Pantai Natsepa yang terletak di desa Suli yang merupakan salah satu desa adat di provinsi Maluku menyimpan beragam tradisi dan warisan budaya seperti tari-tarian tradisional misalnya bambu gila dan sau reka-reka. Selain itu aktivitas sehari-hari dan mata pencaharian masyarakat di desa Suli yang mayoritasnya sebagai nelayan juga dapat dijadikan daya Tarik dimana wisatawan dapat melihat secara langsung kehidupan masyarakat Suli. Pantai Natsepa juga terkenal dengan jajanan khas yaitu rujak Natsepa dan jajanan tradisional lainnya serta didukung dengan sumber daya alam yang sangat menarik yaitu keindahan pantai dan bawah lautnya. Hal ini tentu saja merupakan potensi yang sangat menarik dan dapat dikemas menjadi suatu festival yang beragam dan dapat dilaksanakan dapat waktu yang berbeda agar adanya diversifikasi dan dapat menarik wisatawan untuk datang.

Festival yang dapat dilaksanakan misalnya festival kuliner tradisional, festival perahu dayung, pengadaan pagelaran seni yang diisi dengan tari-tarian tradisional serta permainan tradisional, lomba pemotretan bawah laut dan aktivitas atau kegiatan wisata di pantai Natsepa. Salah satu peluang di Pantai Natsepa yaitu banyak dikunjungi wisatawan harus dimanfaatkan dengan baik, meskipun salah satu kekuatan yang dimiliki Pantai Natsepa adalah kondisi lingkungannya yang aman karena minim tingkat kejahatan namun tetap saja pihak pengelola perlu untuk tetap waspada dan terus mempertahankan kondisi lingkungan yang aman agar wisatawan yang datang berkunjung merasa nyaman dan aman. Pembangunan pos jaga perlu dilakukan untuk terus menjaga lingkungan di dalam dan sekitar Pantai Natsepa, dalam hal ini pengelola dapat bekerja sama dengan masyarakat dan pihak berwajib.

2. Pengadaan sosialisasi dan pelatihan guna meningkatkan kualitas SDM yang ada.

Fasilitasi peningkatan kapasitas/skill produk layanan usaha ekonomi kreatif yang dikembangkan masyarakat lokal di sekitar Kawasan Pantai Natsepa perlu dilakukan agar potensi yang ada dapat dimanfaatkan dengan baik dan dapat terus meningkatkan pelayanan serta dapat meningkatkan standar-standar mutu produk dan pelayanan dasar seperti kebersihan, sanitasi dan higienis, keindahan serta keamanan. Hal ini dapat direalisasikan melalui sosialisasi dan pelatihan. Standarisasi pelayanan dengan tarif yang jelas juga perlu dipahami oleh setiap penyedia jasa serta para wisatawan. Pengembangan produk wisata dapat dilakukan secara bertahap sesuai dengan pertimbangan kapasitas masyarakat, kemampuan pemerintah daerah, serta keuletan pelaku usaha dalam melihat dan mengelola potensi pariwisata menjadi produkproduk yang bermanfaat. Artinya pengembangan produk pariwisata dilakukan tidak dengan cara massal dan dengan perubahan yang drastis tetapi dengan seksama dan bertahap. Prioritas pengembangan dilakukan dengan dukungan program dan kegiatan yang konkret yang terencana. Dengan demikian semua pihak akan belajar dari proses keberhasilan atau kegagalan pengembangan suatu produk wisata. Prinsip suatu pengembangan produk wisata salah satunya adalah proses belajar dari pengalaman bersama. Selain itu pemerintah perlu mempromosikan dan mendorong masyarakat lokal sebagai wujud pelibatan masyarakat lokal dalam industri pariwisata. 
3. Penambahan fasilitas tempat sampah di setiap sudut.

Kondisi lingkungan di Pantai Natsepa juga memprihatinkan karena banyak sampah berserakan dimana-mana, maka dari itu perlu adanya penambahan tempat sampah di setiap sudut dan harus adanya pengawasan dan patroli secara berkala agar lingkungan yang ada tetap terjaga kebersihannya dan bebas dari sampah serta memberikan sanksi bagi setiap pihak yang membuang sampah sembarangan. Pihak pengelola dapat bekerja sama dengan masyarakat sekitar serta pihak swasta untuk membentuk tim atau kelompok untuk mengawasi kebersihan lingkungan di pantai Natsepa.

4. Pengoptimalkan dan meningkatkan promosi dan pemasaran melalui media sosial (Facebook, Twitter, Youtube dsb).

Media ini dapat dijadikan sebagai media komunikasi untuk mengkampanyekan tentang pentingnya menjaga kebersihan di tempat wisata. Meningkatkan hubungan kerja sama dengan berbagai pihak baik swasta maupun masyarakat untuk turut serta dalam mempromosikan Pantai Natsepa. Hal ini tentu saja merupakan wujud dari penguatan kelembagaan yang merupakan salah satu prinsip penting dalam CBT karena kelembagaan adalah tool bagi seluruh anggota komunitas untuk mendapatkan akses untuk menjadi pemegang keputusan.

5. Inventarisir data dan membuat data base yang berisikan informasi tentang potensi yang ada di pantai Natsepa.

Menginventaris dan membuat data Base mengenai setiap potensi yang dimiliki Pantai Natsepa agar dapat memudahkan setiap pihak dalam mengakses informasi yang lebih rinci mengenai Pantai Natsepa beserta potensinya. Hal ini tentu saja merupakan implementasi akan pemanfaatan teknologi yang ada.

\section{Strategi mitigasi dan adaptasi bencana alam}

Pulau Ambon memiliki banyak sesar aktif dan berpotensi gempa bumi oleh karena itu, pelatihan terkait adaptasi dan mitigasi bencana alam perlu dilakukan secara berkala. Strategi mitigasi dan adaptasi yang dapat dilakukan adalah dengan meningkatkan kewaspadaan dini terhadap bencana di masyarakat. Hal ini dapat diwujudkan dengan cara memberikan sosialisasi dan pelatihan kepada masyarakat tentang bencana secara umum khususnya gempa bumi beserta cara penanggulangannya, meningkatkan kerja sama antar sektor dan juga partisipasi masyarakat sekitar sebagai bentuk peningkatan kapasitas yang ada baik untuk pengelola maupun masyarakat, mengembangkan kerangka kebijakan yang berkaitan dengan penanggulangan bencana mulai dari pra-bencana hingga pasca bencana, menentukan tempat evakuasi sementara, membentuk komunitas siaga bencana di Kawasan Pantai Natsepa.

\section{Sosialisasi tentang Sadar Wisata}

Mengadakan sosialisasi sadar wisata kepada masyarakat sekitar objek wisata serta menyediakan media kampanye tentang sadar wisata seperti papan atau signage yang berisi himbauan dan peringatan yang berkaitan dengan sadar wisata, memasang CCTV agar mempermudah pihak pengelola dalam memantau situasi dan kondisi terkini di Pantai Natsepa dalam hal ini berkaitan dengan ancaman gempa bumi dan juga kondisi lingkungan yang kotor karena banyak sampah berserakan. Selain itu pihak pengelola juga perlu mengadakan event 
bersih pantai setiap minggu, hal ini dilakukan untuk mengajak dan mengedukasi wisatawan dan masyarakat mengenai pentingnya membuang sampah pada tempatnya dan juga untuk peduli terhadap lingkungan serta fasilitas yang dibangun tidak boleh bersifat permanen mengingat rawan akan gempa bumi.

\section{E. SIMPULAN}

Pantai Natsepa memiliki banyak potensi fisik maupun non-fisik yang dapat dikembangkan menjadi wisata bahari. Hal ini dikarenakan pemandangan alam berupa hamparan pasir putih yang bersih, air laut yang jernih yang berpotensi untuk dijadikan wisata bahari sebagai kegiatan wisata untuk para wisatawan. Selain itu memiliki beraneka ragam biota laut, terumbu karang yang terdapat di bawah laut sehingga pantai ini cocok untuk kegiatan wahana air (wisata bahari), hal ini didukung oleh adanya potensi yang dimiliki Pantai Natsepa. Potensi yang dimiliki Pantai Natsepa yang sesuai kenyataan adalah lintas jalur yang strategis dan mudah untuk dijangkau serta tersedianya sarana akomodasi, fasilitas dll. Meskipun memiliki banyak potensi fisik dan non-fisik, dalam pelaksanaan kegitan wisaata di pantai Natsepa mempunyai kelemahan dan ancaman yang dapat menghambat proses kegitan wiata di pantai ini. Hambatan dan tantangan tersebut mulai dari kondisi fasilitas yang kurang layak dan tidak terawat, sampah, keunikan atraksi dari karakter dan budaya lokal yang masih sangat minim serta adanya ancaman bencana alam.

Potensi yang dimiliki oleh pantai Natsepa tentu saja perlu dikembangkan secara optimal maka dari itu sangat dibutuhkan perencanaan secara baik dan benar serta harus adanya sinergitas antara berbagai pihak agar setiap aktivitasnya dapat berjalan dengan lancar. Pengelolaan pariwisata harus didasarkan pada perencanaan yang matang, dimana memperhitungkan sesuatu untuk memenuhi kebutuhan dimasa yang akan datang dan mampu mewujudkan kesejahteraan di masyarakat. Peran pemerintah sebagai pengelola harus lebih optimal demi mewujudkan pariwisata yang berkelanjutan di suatu objek wisata bahari. Selain itu, diperlukan suatu strategi pengembangan sebagai solusi untuk menangani kelemahan dan ancaman yang ada agar seluruh kegiatan pengembangan pantai Natsepa dapat terlaksana dengan baik.

Secara praktis, hasil dari penelitian ini berisi tentang hasil identifikasi faktor internal dan external yang menjadi penghambat dan pendorong dalam pengembangan pantai Natsepa beserta rekomendasi strategi dengan pendekatan pariwisata berbasis masyarakat sebagai solusi dalam menghadapi hambatan yang ada.

\section{Referensi}

Anstrand, Melker., (2006). Community-Based Tourism and Sicio-Culture Aspects Relating to Tourism a Case Study of a Swedish Student Excursion to Babati (Tanzania). Laporan tidak diterbitkan.

Hiariey, L. S., (2011). Strategi Peningkatan Kesejahteraan Pelaku Usaha di Sekitar Kawasan Wisata Pantai Natsepa Pulau Ambon. Tesis Universitas Pattimura, pp. 1-102.

Handayawati et al. (2010). Potensi Wisata Alam Pantai-Bahari Retrieved from http:// Analisis Potensi Wisata Alam Bahari.html.

Irawati, N. \& Prakoso, A. A., (2016). Terapan Brand "Jogja Istimewa" Terhadap Pengembangan Pariwisata Berbasis Community Based Tourism (Cbt) Di Yogyakarta. Jurnal Kepariwisataan Stipram, 10 (3), pp. 65-80.

Kiswantoro, Amin. Sabda Riesa W. 2(016). Analisa Kesadaran Wisata Masyarakat Desa Wisata Kebon Agung Kecamatan Imogiri Kabupaten Bantul Terhadap Minat Kunjung Wisatawan.

Jurnal Kepariwisataan Stipram 10(2), pp57-70. http://ejournal.stipram.net/index.php/pariwisata/issue/view/7

64 | Barista: Jurnal Kajian Bahasa dan Pariwisata, Volume 6 Nomor 2, 2019: 49-65 
Prabawati, Hemas Jakti P., (2013). Faktor Faktor Keberhasilan Community Based Tourism Dalam Pengembangan Desa Wisata (Studi Kasus:PNPM Mandiri Pariwisata di Dataran Tinggi Dieng). Tugas Akhir Tidak Diterbitkan, Jurusan Perencanaan Wilayah dan Kota, Fakultas Teknik Universitas Diponegoro, Semarang

Purnamasari, Andi Maya,. (2011) Pengembangan Masyarakat Untuk Pariwisata di Kampung Wisata Toddabjo Provinsi Sulawesi Selatan. Jurnal Perencanaan Wilayah dan Kota, 22(1), pp.4964

Republik Indonesia. Undang-Undang Tentang Kepariwisataan, UU No.10 Tahun 2009.Jakarta:Direktorat Jenderal Hukum dan HAM.

Republik Indonesia. Undang-Undang Tentang Kepariwisataan, UU No.32 Tahun 2004.Jakarta:Direktorat Jenderal Hukum dan HAM.

Suansri, Potjana., (2003). Community Based Tourism Handbook. Thailand: REST Project.

United Nations Economic and Social Commission for Asia and the Pacific, UNESCAP, (2003), Poverty Alleviation Through Sustainable Tourism Development: 7 Retrieved from http:// books. google.co.id. 